\section{UJMM

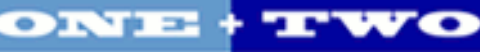

Volume 3 | 2010 Fall

\section{Undergraduate Journal of Mathematical}

Modeling: One + Two

2010

\title{
Canal Lock Displacement
}

Rick Blanton

University of South Florida

Advisors:

Thomas Bieske, Mathematics and Statistics

Ronnie Cathcart, Utopia Marine Company Owner

Problem Suggested By: Ronnie Cathcart

Follow this and additional works at: https://digitalcommons.usf.edu/ujmm

Part of the Mathematics Commons

UJMM is an open access journal, free to authors and readers, and relies on your support:

Donate Now

\section{Recommended Citation}

Blanton, Rick (2010) "Canal Lock Displacement," Undergraduate Journal of Mathematical Modeling: One + Two: Vol. 3: Iss. 1, Article 1.

DOI: http://dx.doi.org/10.5038/2326-3652.3.1.13

Available at: https://digitalcommons.usf.edu/ujmm/vol3/iss1/13 


\title{
Canal Lock Displacement
}

\begin{abstract}
In this project we determine the time needed for a pump to raise the water level in a canal lock in order for a boat to continue upstream. Using calculus methods and elementary physics, it was determined that it would take roughly 5 minutes for a single 60 horsepower pump to raise the water level the required 10 feet. We conclude that the lock is fairly efficient but offer some suggestions to increase the time efficiency of the lock system.
\end{abstract}

\section{Keywords}

Work, Water Displacement, Water Pump

Creative Commons License

(c) (i) ()

This work is licensed under a Creative Commons Attribution-Noncommercial-Share Alike 4.0 License.

\section{Erratum}

This article was previously called Article 13. 


\section{TABLE OF CONTENTS}

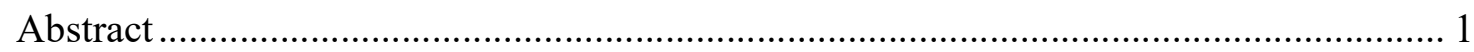

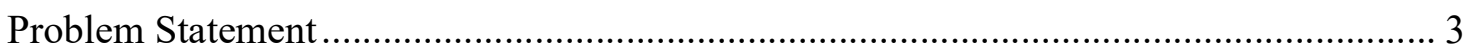

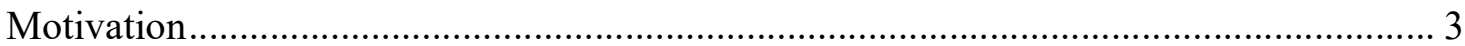

Mathematical Description and Solution Approach........................................................... 3

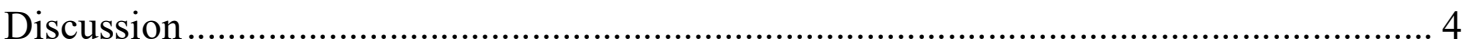

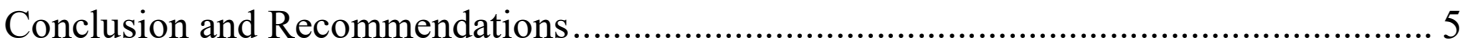

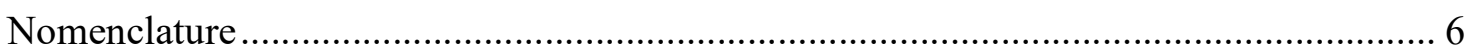

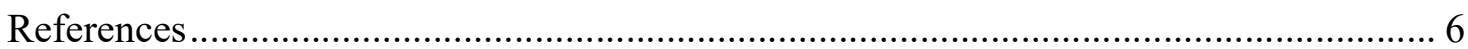




\section{PROBLEM STATEMENT}

Located on a canal is a lock with dimensions of $100 \mathrm{ft}$ by $30 \mathrm{ft}$ and a standing water level of $10 \mathrm{ft}$. This lock must raise the water level to $20 \mathrm{ft}$ in order for boats to continue upstream. If the water is pumped in by a $60 \mathrm{HP}$ engine, how long will it take the raise the water level to $20 \mathrm{ft}$ ?

\section{MOTIVATION}

This problem is merely a daily occurrence on many major waterways, including those vital to trade such as the Panama Canal and Mississippi River. When locks were first created they revolutionized trade, making it much easier for ships to travel upstream. This problem is useful to engineering as it allows engineers to estimate the time needed for a ship to pass through each lock.

\section{MATHEMATICAL DESCRIPTION AND SOLUTION APPROACH}

In order to solve the problem, we first needed to calculate work necessary to raise the water level from $10 \mathrm{ft}$ to $20 \mathrm{ft}$. To accomplish this we break the water in the lock into infinitesimally thin sheets and calculate the weight of each sheet using:

$$
\text { Force }=\text { Weight }(\text { sheet })=\text { Volume } \times \text { Density } .
$$

Knowing the density of water $\left(62.4 \mathrm{lbs} / f \mathrm{t}^{3}\right)$, the dimensions of the lock, and letting $d D$ represent the height of each sheet (1) yields:

$$
F=\text { Weight }(\text { sheet })=3,000 f t^{2} \times d D \times 62.4 l b /_{f t^{3}}=187,200 \times d D .
$$


To calculate the work done on each sheet we used,

$$
\text { Work }(\text { sheet })=\text { Weight }(\text { sheet }) \times(D-10)=187,200 d D \times(D-10)
$$

where $(D-10)$ represents the height each sheet was raised. Thus to calculate the total work done on the water in the lock we summed over all sheets which became the definite integral:

$$
W=\int F d D=\int_{10}^{20}[187200 \times(D-10)] d D=9,360,000 \text { ft lbs }
$$

Then to determine how fast the water would fill the lock we used the formula,

$$
P=W / T
$$

and the conversion factor:

$$
1 H P=33,000 \mathrm{ft} \text { lbs/minute. }
$$

Given that the power was supplied by a single $60 \mathrm{HP}$ engine combining (4), (5) and (6) gives:

$$
T=W / P=9,360,000 /(60 \times 33,000) \approx 4.73 \text { minutes }
$$

Thus we concluded approximately 4.73 minutes are required to raise the water level in the lock $10 \mathrm{ft}$.

\section{DISCUSSION}

While completing this project we determined that 9,360,000 ft lbs of work were required to raise the water level in the lock from $10 \mathrm{ft}$ to $20 \mathrm{ft}$. We also found that using a single $60 \mathrm{HP}$ engine it would take approximately 4.73 minutes to fill the lock to the desired level so a boat could continue upstream. Had this been a field study it could have created 
incentive to work towards faster pumping times to ultimately allow more ships to pass through the lock system.

\section{CONCLUSION AND RECOMMENDATIONS}

These results suggest that the lock is rather efficient, but there is room for improvement. One way to make this lock more efficient is to reduce the dimensions of the lock to $80 \mathrm{ft}$ by $30 \mathrm{ft}$. However, powering the lock with two pumps is probably the most efficient option. This would cut the fill time down to nearly 2 minutes. Similar to this problem, it would be interesting to do a study to calculate the time necessary for the lock to lower a ship from $20 \mathrm{ft}$ to $10 \mathrm{ft}$ of water. 


\section{NOMENCLATURE}

\begin{tabular}{|clc|}
\hline Symbol & Description & Unit \\
\hline$F$ & Force & $l b s$ \\
\hline$D$ & Distance & $f t$ \\
\hline$W$ & Work & $\mathrm{ft} \mathrm{lbs}$ \\
\hline$P$ & Power & $\mathrm{ft} l \mathrm{lbs} / \mathrm{min}$ \\
\hline$H P$ & Horsepower & $\mathrm{ft} l \mathrm{lbs} / \mathrm{min}$ \\
\hline$T$ & Time & $\mathrm{min}$ \\
\hline
\end{tabular}

\section{REFERENCES}

Halliday, Resnick, Walker. Fundamentals of Physics 7th Edition. Hoboken, New Jersey: John Wiley \& Sons, 2005.

Larson, Ron, Robert Hostetler and Bruce Edwards. Calculus. 8th Edition. Boston, MA: Houghton Mifflin Company, 2005. 